\title{
The Criminal Sanction Policy Against Victims Of Criminal Activities In Household
}

\author{
Sekaring Dyah Ika Wulan*) and Sri Endah Wahyuningsih**) \\ *) Civil Servant of Indonesia, E-mail: sekaring mh36@std.unissula.ac.id \\ $\left.{ }^{* *}\right)$ Faculty of Law Universitas Islam Sultan Agung
}

\begin{abstract}
The research objectives in this study are to: examine and analyze the policy of criminal sanctions against victims of domestic violence in the Law on the Elimination of Domestic Violence, to examine and analyze the constraints of criminal sanctions policies against victims of domestic violence, to examine and analyze the policy of criminal sanctions against victims of domestic violence in the future. This thesis uses a normative juridical approach, with a descriptive analytical research method. The data used are primary and secondary data which will be analyzed qualitatively. The research problems were analyzed using the theory of legal protection and the theory of justice. The results of the study conclude that acts of violence that occur in the household are also the same as other forms of crime in general, however, domestic violence has a special nature and characteristics that lie in the relationship between the perpetrator and the victim, as well as the ways of solving it. The obstacles to the policy of criminal sanctions against victims of domestic violence are: 1). The purpose of sentencing is not merely as a retaliation for the actions of the defendants in order to become a deterrent. 2). Weak corners of the basic idea of the double track system. 3). Weak legal sanctions given to domestic violence defendants. The Drafting Team of the Criminal Code has made a rating based on the gravity of criminal acts. This rating is divided into five levels using a semantic scale technique, from "very light" to "very serious" with a note that "very light" crimes are not subject to deprivation of liberty, while very serious crimes are crimes that are subject to deprivation of liberty/imprisonment for more than seven years.

Keywords: Criminal Sanctions; Crime; Domestic Violence.
\end{abstract}

\section{Introduction}

Crime can be interpreted criminologically and juridically. Crime in the sense of criminology is a human act that tarnishes the basic norms of society. This is intended as the actions of individuals who violate the rules that live and thrive in society. Juridical crime, i.e. an evil act or evil act in the sense of criminal law means that the crime is formulated in criminal regulations. ${ }^{1}$

Act No. 23 of 2004 concerning the Elimination of Domestic Violence, states the protection of the rights of victims, as regulated in Article 10: Victims have the right to:

- protection from the family, police, prosecutors, courts, advocates, social institutions, or other parties, either temporarily or based on the stipulation of a protection order from the court;

- health services according to medical needs;

1Yusril I A, Bambang Tri Bawono and Ira Alia Maerani, Criminal Investigation of Motorcycle Stealing Goods. Law Development Journal ISSN : 2747-2604 Volume 3 Issue 1, March 2021, (169 - 174). 
- handling specifically related to the confidentiality of the victim;

- assistance by social workers and legal assistance at every level of the examination process in accordance with the provisions of the legislation; and

- spiritual guidance service.

Several weaknesses exist in the PKDRT Law. With the alternative system of sanctions listed in the Act above, it can lead to misinterpretation of law enforcement to be able to choose alternatives for imposing criminal sanctions in order to be free from imprisonment. In addition, the inclusion of a maximum sanction without including a minimum limit can create legal uncertainty. The perpetrator may only be sentenced to the minimum and lightest sentence which is not commensurate with the act he has committed. This is the reason why many victims are reluctant to complain about the acts of domestic violence they have experienced because it will only be a waste of time and cannot fulfill their sense of justice for victims of domestic violence.

For modern countries, the desire to effectively guarantee the rights of citizens and regulate the orderly state administration has encouraged every country to adopt constitutionalism, including the legal regulation of domestic violence. ${ }^{2}$ The settlement of criminal cases is carried out through the evidentiary process, namely the prosecution process which is carried out directly in an experiment. ${ }^{3}$ In judicial practice, the process always begins with an arrest, detention, then being prosecuted by the public prosecutor, which ends with a judge's decision. ${ }^{4}$

The police is a subsystem in the criminal justice system that is sufficient to determine the success and work of the entire system in providing services to the public. ${ }^{5}$ One of the efforts in overcoming the rise of victims of domestic violence is in empowering women, namely participating in the Ministry of Women's Empowerment and Child Protection (KP2PA) program, namely: 1) improving women's quality of life and child protection, 2) strengthening gender mainstreaming institutions, 3) harmonizing policies for improving quality of children and women, 4) increased participation and gender equality in development. ${ }^{6}$

Legal protection for children as victims of crime can include forms of protection that are abstract (indirect) or concrete (direct). Abstract Protection is basically a form of protection that can only be enjoyed or felt emotionally (psychically), such as a sense of satisfaction. Meanwhile, concrete protection is

\footnotetext{
${ }^{2}$ Adhe I smail A, Constitutionalism Concept in Implementation of Indonesian State Administration. Jurnal Daulat Hukum Volume 4 Issue 2, June 2021 ISSN: 2614-560X. http://jurnal.unissula.ac.id/index.php/RH/article/view/15737/5567.

${ }^{3}$ Ardito, Y P, Umar Ma'ruf and Aryani Witasari. Implementation of Criminal Action Prosecution Online in Realizing Principle of Fast Prosecution, Simple \& Low Cost, Jurnal Daulat Hukum, Volume 4 Issue 2, June 2021 ISSN: 2614-560X. http://jurnal.unissula.ac.id/index.php/RH/article/view/15737/5567. ${ }^{4}$ Feri, S W, and Arpangi. Settlement Policy of Criminal Actions which Performed by Children through Penal Mediation. Jurnal Daulat Hukum Volume 4 Issue 2, June 2021 ISSN: 2614-560X. http://jurnal.unissula.ac.id/index.php/RH/article/view/15737/5567.

${ }^{5}$ Nurfita A T, Sri Endah Wahyuningsih and Arpangi. The Police Role in Investigating the Crime of Child Murder as a Result of Infidelity Relationships. Law Development Journal ISSN : 2747-2604 Volume 3 Issue $\quad 1, \quad$ March $\quad 2021, \quad$ (86 2 92). http://jurnal.unissula.ac.id/index.php/ldj/article/view/14866/5481.

${ }^{6}$ Sri Kusriyah, "Kebijakan Pemerintah Daerah Dalam Pemberdayaan Perempuan di Kabupaten Demak”, Jurnal Pembaharuan Hukum, Vol. IV No.1, January-April 2017, p. 120
} 
basically a form of protection that can be enjoyed in real terms, such as gifts in the form of material or non-material nature. Material gifts can be in the form of compensation or restitution, exemption from living expenses or education. The provision of non-material protection can be in the form of release from threats, from news that demeans human dignity. ${ }^{7}$

Policies or efforts to overcome crime are essentially an integral part of efforts to protect society (social defense) and efforts to achieve social welfare. Therefore, it can be said that the ultimate goal or main goal of criminal politics is the protection of society to achieve public welfare. ${ }^{8}$

Thus, there is a need for a change in the sense of reviewing Indonesian criminal law which so far is still based on the philosophical principles and foundations of foreign nations towards a criminal law system based on the values of the One Godhead as the values of national and state life which aspired to. ${ }^{9}$ The resolution of conflicts that occur in the community can be done with two options, namely litigation and non-litigation. Litigation is a way of solving problems through the Court, while non-litigation is a way of solving problems outside the Court. In the perspective of criminal law in Indonesia, it is already familiar with the settlement of criminal cases outside the court ${ }^{10}$

From this background, this paper is intended to analyze the formulation of criminal law policies in the context of overcoming the crime of domestic violence. Determining the purpose of punishment can be the basis for determining the methods, means or actions that will be used in the context of overcoming the crime of domestic violence.

The purpose of this study is to examine and analyze the policy of criminal sanctions against victims of domestic violence in the Law on the Elimination of Domestic Violence, to examine and analyze the constraints of criminal sanctions policies against victims of domestic violence, and to examine and analyze the policies of criminal sanctions against victims of criminal acts. Domestic violence in the future.

\section{Research Methods}

The approach method used in this study uses a normative juridical method, namely in addition to using legal principles and principles in reviewing, viewing, and analyzing problems, as they are, ${ }^{11}$ which in this case relates to the policy of criminal sanctions against victims of criminal acts of domestic violence in the Law on the

\footnotetext{
${ }^{7}$ Sri Endah Wahyuningsih, "Perlindungan Hukum Terhadap Anak Sebagai Korban Tindak Pidana Kesusilaan Dalam Hukum Pidana Positif Saat Ini", Jurnal Pembaharuan Hukum, Vol. III, No. 2, MayAugust 2016, p. 173

8Barda Nawawi Arief, 2008, Bunga Rampai Kebijakan Hukum Pidana Perkembangan Penyusunan Konsep KUHP Baru, Kencana, Jakarta, p. 4.

${ }^{9}$ Sri Endah Wahyuningsih, "Urgensi Pembaharuan Hukum PIdana Materiel Indonesia Berdasarkan Nilai-Nilai Ketuhanan Yang Maha Esa", Jurnal Pembaharuan Hukum Vol. 1 No. 1, January-April 2014, p. 21

${ }^{10}$ Arif Septria Hendra Saputra, Gunarto, Lathifah Hanim, "Penerapan Restorative Justice Sebagai Alternatif Penyelesaian Tindak Pidana Penganiayaan di Satreskrim Polsek Lasem", Jurnal Daulat Hukum, Vol. 1 No. 1, March 2018, p. 10-11.

${ }^{11}$ Soerjono Soekanto, 2010, Pengantar Penelitian Hukum, Universitas Indonesia Press, Jakarta, p. 10.
} 
Elimination of Domestic Violence. The specifications in this study are analytical descriptive. Descriptive research is a research method that is intended to systematically and accurately describe the facts and characteristics of the research field.

Sources of data used in this study are primary, secondary, and tertiary data sources. Primary data sources are objects that are observed directly in the field and interviewed informants. Primary legal materials consist of: Act No. 23 of 2004 concerning the Elimination of Domestic Violence. Tertiary legal materials consist of dictionaries, encyclopedias.

The data collection method used to obtain data that has a relationship with the object of research is interviews with resource persons and document review, while the data analysis method used is qualitative data analysis in this study including data reduction, data presentation and conclusions/verification.

\section{Result and Discussion}

\subsection{Policy on Criminal Sanctions Against Victims of Criminal Acts of Domestic Violence in the Law on the Elimination of Domestic Violence}

Domestic Violence (KDRT) tends to be perpetrated by men in a young age group, not working, not in a legal marriage, possibly having witnessed domestic violence as a child, as well as having psychiatric problems that range from depression to substance abuse. . Some other situations that need attention to the possibility of domestic violence are problems related to drugs and alcohol, situations related to stress and depression.

In general, in every act between the perpetrator and the victim, they often do not know each other and even seem foreign. Indeed, there are some criminal acts committed by people who already know each other (friends, friends, neighbors), as well as people who are related by blood. In fact, the forms of acts of violence that occur in the household are also the same as other forms of criminal acts in general, such as persecution as regulated in Article 351 of the Criminal Code, murder (Article 338 of the Criminal Code), rape (Article 285 of the Criminal Code), and humiliation (Article 310 of the Criminal Code). Adultery (Article 284 of the Criminal Code) and other acts that can be categorized as criminal acts as regulated in the Criminal Code. However, domestic violence has a special nature and characteristics that lie in the relationship between the perpetrator and the victim, as well as the ways of solving it. 12

With the determination of several types of domestic violence as a complaint offense, the legislators (the Law on the Elimination of Domestic Violence) have acknowledged the existence of a private/private element in the case of domestic violence.

Relative complaint offenses are certain types of crimes, in which case it is only determined that the complaint is a condition, if there is a certain relationship between the maker and the complainant. A certain relationship between the maker and the complainant is the relationship of blood families in a straight line (father,

12 Interview with Aiptu Puguh Budi Utomo, SH (Investigator), On September 23, 2020 at 15.00 WIB. 
grandmother, children, grandchildren) or in the second degree of a deviant line (siblings) and marital families in a straight line (in-law, son-in-law) or in the second degree of the deviated line (in-law).

Family relationships must be stated at the time of filing a complaint. Prosecution is limited to the person named in the complaint. If, for example, only the perpetrator of the crime is mentioned, then the criminal assistant, who may also have a close family, cannot be prosecuted. Thus, this complaint can be divided (splitsbaar). From the articles listed regarding the complaint offense, the use of the term "prosecution can only be carried out if there is one". So that sentence raises the thought or opinion that thus the investigation can be carried out by the legal officer for preventive purposes.

\subsection{Obstacles to Criminal Sanctions Policy Against Victims of Domestic Violence}

The obstacles to the policy of criminal sanctions against victims of domestic violence are:

- The purpose of sentencing is not merely as retaliation for the actions of the defendants to become a deterrent

The purpose of sentencing is not merely as retaliation for the actions of the defendants to be a deterrent, but aims to foster and educate so that the defendants realize and realize their mistakes, so that they will not commit criminal acts again and can become good members of society in the future or with the aim of emphasis on protecting the family in society. Thus, it is not the level of sanctions that are given, but what is important is education and guidance for the accused and the protection of the community.

- Weak corners of the basic idea of the double track system.

From the point of view of the basic idea of a double track system, the equal position of criminal sanctions and action sanctions is very useful for maximizing the two types of sanctions appropriately and proportionally, because the policy of sanctions is integral and balanced (criminal sanctions and actions), in addition to avoiding the application of fragmentary sanctions (which always emphasizes criminal sanctions) also ensures the integration of individual sanctions systems and functional sanctions systems.

- Weak legal sanctions given to domestic violence defendants

It is hoped that by giving sanctions to defendants who commit crimes of domestic violence, the defendant can improve his behavior and repair his household so that it can be better so that the house is a safe place for his wife and children because they feel protected, respected and there is love from her husband.

\subsection{Criminal Sanction Policy Against Victims of Criminal Acts of Domestic Violence in the Future}

In its implementation, the PKDRT Law uses an alternative formulation system in the form of threats of imprisonment or fines. The form of this formulation is contained in Chapter VIII of Article 44 (physical violence), Article 45 (psychic 
violence), Article 46, Article 47 and Article 48 (sexual violence), and Article 49 (abandonment).

Article 44 of the Law on the Elimination of Domestic Violence determines:

- Everyone who commits acts of physical violence within the scope of the household as referred to in Article 5 letter a, shall be sentenced to a maximum imprisonment of 5 (five) years or a maximum fine of IDR 15,000,000.

- In the event that the act as referred to in paragraph (1) causes the victim to fall ill or is seriously injured, the person shall be sentenced to a maximum imprisonment of 10 years or a maximum fine of IDR 30,000,000.-

- In the event that the act as referred to in paragraph (2) results in the death of the victim, the person shall be punished with a maximum imprisonment of 15 years or a maximum fine of IDR 45,000,000.-

- In the event that the act as referred to in paragraph (1) is carried out by the husband against the wife or vice versa which does not cause disease or obstacles to carry out the work of the position or livelihood or daily activities, the person shall be punished with imprisonment for a maximum of 4 months or a fine of a maximum of IDR 5,000. .000,-

Article 45 of the Law on the Elimination of Domestic Violence determines:

- Everyone who commits acts of psychological violence within the household as referred to in Article 5 letter $b$ shall be sentenced to a maximum imprisonment of 3 (three) years or a maximum fine of IDR 9,000,000.00 (nine million rupiah).

- In the event that the act as referred to in paragraph (1) is carried out by a husband against his wife or vice versa which does not cause disease that prevents him from carrying out his official job or livelihood or daily activities, he shall be sentenced to a maximum imprisonment of 4 (four) months or a maximum fine of IDR 3,000,000.00 (three million rupiah).

This provision on psychological violence carries a lighter penalty than other provisions on violence in the household sphere. Whereas the consequences of this psychological violence are as severe as physical violence because it is related to selfesteem, although this psychological violence does not leave physical scars so it is difficult to see with the naked eye. But psychological violence can cause stress to the victim, from this stress it can make the body weak so that it is easy to fall ill.

Article 46

The Law on the Elimination of Domestic Violence stipulates: Everyone who commits acts of sexual violence as referred to in Article 8 letter a shall be sentenced to a maximum imprisonment of 12 (twelve) years or a maximum fine of IDR 36,000,000.00 (thirty six million rupiah).

Article 47

The Law on the Elimination of Domestic Violence stipulates: Anyone who forces a person who lives in his household to have sexual relations as referred to in Article 8 letter $\mathrm{b}$ shall be sentenced to a minimum imprisonment of 4 (four) years and a maximum imprisonment of 15 (fifteen) years or a minimum fine of IDR $12,000,000.00$ (twelve million rupiah) or a maximum fine of IDR 300,000,000.00 (three hundred million rupiah).

Article 48 
The Law on the Elimination of Domestic Violence stipulates: In the event that the acts as referred to in Article 46 and Article 47 result in the victim receiving injuries that do not give any hope of recovery at all, experiencing mental or mental disorders for at least 4 (four) weeks continuously or 1 (one) non-consecutive year, the loss or death of the fetus in the womb, or resulting in the non-functioning of the reproductive organs, shall be punished with a minimum imprisonment of 5 (five) years and a maximum imprisonment of 20 (twenty) years or a minimum fine of IDR $25,000,000.00$ (twenty five million rupiah) and a maximum fine of IDR $500,000,000.00$ (five hundred million rupiah).

Article 49

The Law on the Elimination of Domestic Violence determines:

Sentenced to a maximum imprisonment of 3 (three) years or a maximum fine of IDR 15,000,000.00 (fifteen million rupiah), every person who:

- Abandoning other people within the scope of their household as referred to in Article 9 paragraph (1);

- Abandoning other people as referred to in Article 9 paragraph (2).

In this case of neglect, it does not explain the difference in criminal sanctions against economic neglect or neglect of physical and spiritual livelihood. If the neglect that occurs is only economic neglect, then the imposition of imprisonment is not appropriate, it would be better if the punishment imposed is in the form of fines with minimum and maximum limits and compensation for victims who are neglected. So the victim feels that their rights are fulfilled by the law.

The judge's decision in imposing a sentence on the perpetrator is entirely in the hands of the judge. If we examine more deeply the PKDRT Law which adheres to an alternative criminal formulation in the form of imprisonment or a fine, the judge may decide by imposing a fine only. The existence of this choice will greatly benefit the perpetrator, so that the perpetrator does not need to serve a prison sentence for a certain period of time. Perpetrators are still free to roam and it is likely that the victim will feel insecure and uncomfortable. While the inclusion of a maximum criminal threat only provides an opportunity for the perpetrator to receive a low criminal sanction because there is no minimum limit.

In addition, if the consequences of domestic violence do not cause disease or obstacles to carry out daily activities, it is determined as a complaint offense as referred to in Article 51, Article 52, and Article 53 which reads as follows:

Article 51

The crime of physical violence as referred to in Article 45 paragraph (4) is a complaint offense.

Article 52

The criminal act of psychological violence as referred to in Article 45 paragraph (2) is a complaint offense.

The final part of the Law on the Elimination of Domestic Violence contains criminal provisions, with several forms of punishment, namely imprisonment, fines and criminal supervision. The amount of imprisonment and fines is in the range of one year to fifteen years, which seems to refer to the provisions in the Criminal Code, because the parameters of this criminal determination have never been described, as are other regulations. A parameter for the determination of criminal sanctions 
can only be created if it has been agreed in advance what to think as a basis for thinking for punishment. With regard to the parameters of criminal determination, the Drafting Team of the Criminal Code has made a rating based on the gravity of criminal acts. This rating is divided into five levels using a semantic scale technique,

It is a pity that the construction of this scale was not developed further. Therefore, there are again problems in determining the proportion of each crime, both in terms of parity, ranking and qualitative distance (parity, rank-ordering and spacing) between one crime and another. It is not explained how the Formulating Team determines the category of criminal acts, but it seems that there has not been a specific method so that the classification, ranking and determination of criminal sanctions are still similar to the Criminal Code, as is also found in the PKDRT Law.

Efforts to determine this proportion are not easy at all, but are very important for consistency, not only at the level of legislation but also at the level of implementation by the judiciary in the future. Closely related to this is the parameter of punishment in the formulation of sanctions. Barda Nawawi and Soedarto have complained about this condition. It is certain that the absence of this parameter is not only a technical problem, but also a philosophical problem, in connection with the absence of a sentencing philosophy. This condition is made worse because the legislative process as a political process that produces laws that apply to all Indonesian people has not been satisfactory until now. The existence of logrolling or vote trading, quite a lot gives color to this process. In addition, the brewing mechanism, which is still being debated, low public participation, and the ability of legislators themselves are the most significant factors in determining the quality of legislative products. This is even more pronounced when looking at the products of criminal law, because this process is basically a political process with political arguments. To determine the behavior that is deemed appropriate to be threatened with criminal sanctions, and then, the type and amount of punishment that is appropriate to be threatened with such behavior. Determination of behavior that is formulated as a criminal act should begin with the question: whether a behavior should be submitted to private ethics or whether it has become part of the public domain. The majority of citizens, including legal experts, tend to take for granted behavior that is formulated as a crime and its criminal sanctions which can be based solely on informed acceptance or indifference. Whether this reflects their absolute trust in the legislature, or the ignorance of the public, has never been investigated.

\section{Closing}

The conclusion in this study is that acts of violence that occur in the household are also the same as other forms of crime in general, such as persecution. However, domestic violence has a special nature and characteristics that lie in the relationship between the perpetrator and the victim, as well as the ways of solving it. The obstacles to the policy of criminal sanctions against victims of domestic violence are: 1). The purpose of sentencing is not merely as a retaliation for the actions of the defendants in order to become a deterrent. 2). Weak corners of the basic idea of the double track system. 3). Weak legal sanctions given to domestic violence defendants. The Drafting Team of the Criminal Code has made a rating based on the gravity of criminal acts. This rating is divided into five levels using a 
semantic scale technique, from "very light" to "very serious" with a note that "very light" crimes are not subject to deprivation of liberty, while very serious crimes are crimes that are subject to deprivation of liberty/ imprisonment for more than seven years.

The suggestion in this research is that the form of legal protection for victims of domestic violence must be in accordance with justice, namely by paying attention to the rights of victims of domestic violence. The implementation of legal protection for victims of domestic violence should prioritize compliance with applicable laws, because sometimes the implementation of legal protection is still not appropriate.

\section{References}

\section{Journal}

[1] Adhe I smail A, Constitutionalism Concept in Implementation of Indonesian State Administration. Jurnal Daulat Hukum Volume 4 Issue 2, June 2021 ISSN: 2614$560 X$.

[2] Ardito, Y P, Umar Ma'ruf and Aryani Witasari. Implementation of Criminal Action Prosecution Online in Realizing Principle of Fast Prosecution, Simple \& Low Cost, Jurnal Daulat Hukum, Volume 4 Issue 2, June 2021 ISSN: 2614-560X.

[3] Arif Septria Hendra Saputra, Gunarto, Lathifah Hanim, "Penerapan Restorative Justice Sebagai Alternatif Penyelesaian Tindak Pidana Penganiayaan di Satreskrim Polsek Lasem", Jurnal Daulat Hukum, Vol. 1 No. 1, March 2018

[4] Feri, S W, and Arpangi. Settlement Policy of Criminal Actions which Performed by Children through Penal Mediation. Jurnal Daulat Hukum Volume 4 Issue 2, June 2021 ISSN: 2614-560X.

[5] Indah Lestari, Sri Endah Wahyuningsih, Penegakan Hukum Pidana Terhadap Pengguna Narkoba di Polda Jateng, Jurnal Hukum Khaira Ummah, Vol.2 No.3, September 2017.

[6] Nurfita A T, Sri Endah Wahyuningsih and Arpangi. The Police Role in Investigating the Crime of Child Murder as a Result of Infidelity Relationships. Law Development Journal ISSN : 2747-2604 Volume 3 Issue 1, March 2021, $(86-92)$.

[7] Sri Endah Wahyuningsih, "Perlindungan Hukum Terhadap Anak Sebagai Korban Tindak Pidana Kesusilaan Dalam Hukum Pidana Positif Saat Ini”, Jurnal Pembaharuan Hukum, Vol. III, No. 2, May-August 2016.

[8] Sri Endah Wahyuningsih, "Urgensi Pembaharuan Hukum PIdana Materiel Indonesia Berdasarkan Nilai-Nilai Ketuhanan Yang Maha Esa”, Jurnal Pembaharuan Hukum Vol. 1 No. 1, January-April 2014.

[9] Sri Kusriyah, "Kebijakan Pemerintah Daerah Dalam Pemberdayaan Perempuan di Kabupaten Demak", Jurnal Pembaharuan Hukum, Vol. IV No.1, January-April 2017.

[10] Yusril I A, Bambang Tri Bawono dan Ira Alia Maerani, Criminal Investigation of Motorcycle Stealing Goods. Law Development Journal ISSN : 2747-2604 Volume 3 Issue 1, March 2021, (169-174).

\section{Book}


[1] Barda Nawawi Arief, 2008, Bunga Rampai Kebijakan Hukum Pidana Perkembangan Penyusunan Konsep KUHP Baru, Kencana, Jakarta.

[2] Soerjono Soekanto, 2010, Pengantar Penelitian Hukum, Universitas Indonesia Press, Jakarta. 